\title{
Article
}

\section{Losing Faith in the Dead Donor Rule}

\author{
Choong, Kartina Aisha
}

Available at http://clok.uclan.ac.uk/11255/

Choong, Kartina Aisha ORCID: 0000-0001-9407-1771 (2014) Losing Faith in the Dead Donor Rule. Journal of Medical Law and Ethics, 2 (2). pp. 23-35.

It is advisable to refer to the publisher's version if you intend to cite from the work.

http://dx.doi.org/10.7590/221354014X14042206275951

For more information about UCLan's research in this area go to

http://www.uclan.ac.uk/researchgroups/ and search for <name of research Group>.

For information about Research generally at UCLan please go to http://www.uclan.ac.uk/research/

All outputs in CLoK are protected by Intellectual Property Rights law, including Copyright law. Copyright, IPR and Moral Rights for the works on this site are retained by the individual authors and/or other copyright owners. Terms and conditions for use of this material are defined in the policies page.

\section{CLoK}

Central Lancashire online Knowledge www.clok.uclan.ac.uk

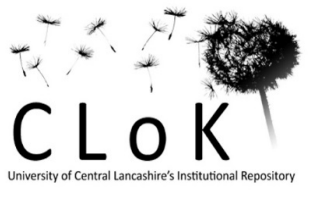




\section{LOSING FAITH IN \\ THE DEAD DONOR RULE}

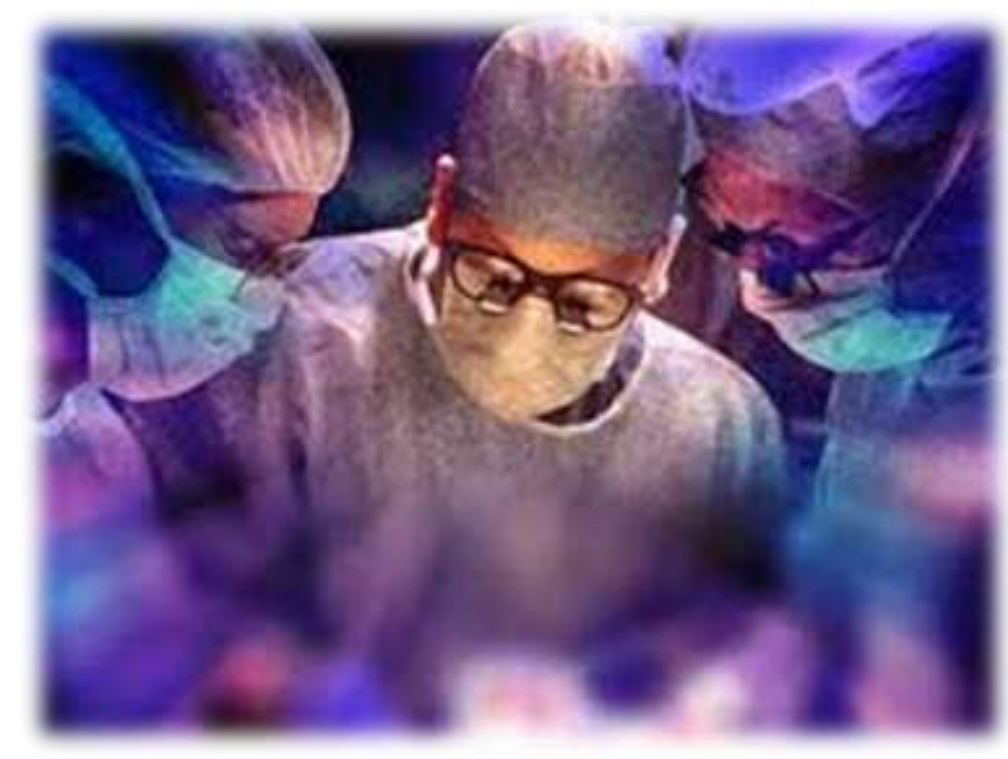

\section{Dr Kartina Aisha Choong}

The David Price Memorial Seminar Series De Montfort University, 16 December 2013
INNOVATIVE THINKING FOR THE REAL WORLD 


\section{Outline}

- Organ Donation: A Religious Perspective

- Dead Donor Rule \& Faith Communities

- Recommendations

INNOVATIVE THINKING FOR THE REAL WORLD 


\section{ORGAN DONATION}

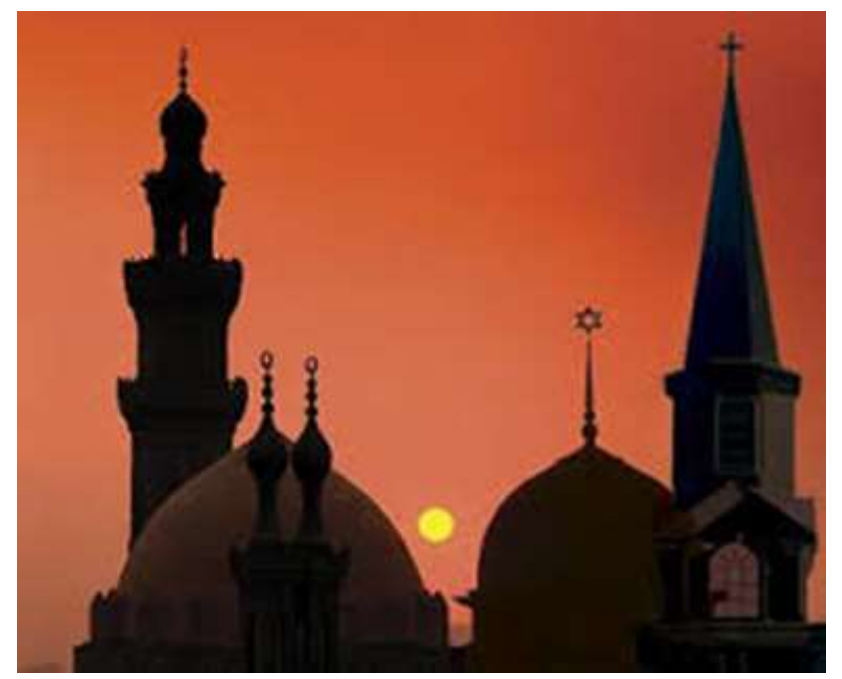

A RELIGIOUS PERSPECTIVE

INNOVATIVE THINKING FOR THE REAL WORLD 


\section{Christianity}

"Greater love has no man than this, that a man lay down his life for his friends"

The New Testament (John 15:13)

INNOVATIVE THINKING FOR THE REAL WORLD 


\section{$\underline{\text { Islam }}$}

"Whosoever saves a life, it shall be as if he has given life to all mankind"

The Quran (Surah Al-Mai'dah, verse 32)

INNOVATIVE THINKING FOR THE REAL WORLD 


\section{Judaism}

\section{"to sustain a single human soul is equivalent to sustaining an entire world" \\ The Mishnah (Sanhedrin 4:5)}




\section{THE DEAD DONOR RULE}

\section{\&}

\section{FAITH COMMUNITIES}

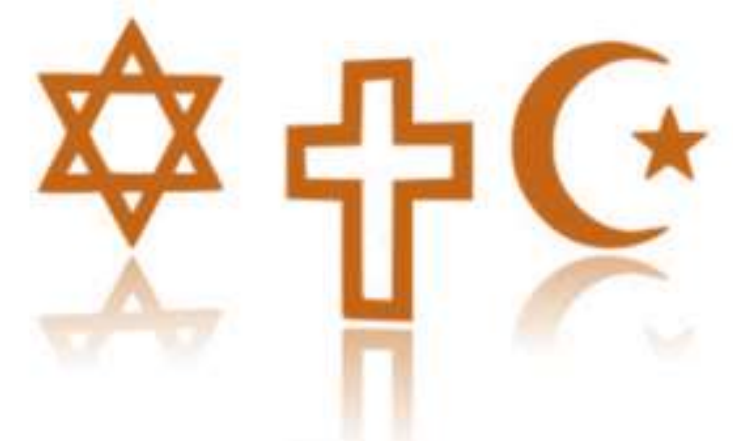

INNOVATIVE THINKING FOR THE REAL WORLD 


\section{The Dead Donor Rule (DDR)}

- Organ retrieval must not kill the donor

- Donor must be declared dead first

INNOVATIVE THINKING FOR THE REAL WORLD 


\section{$\underline{\text { Rationale }}$}

1) To protect vulnerable groups
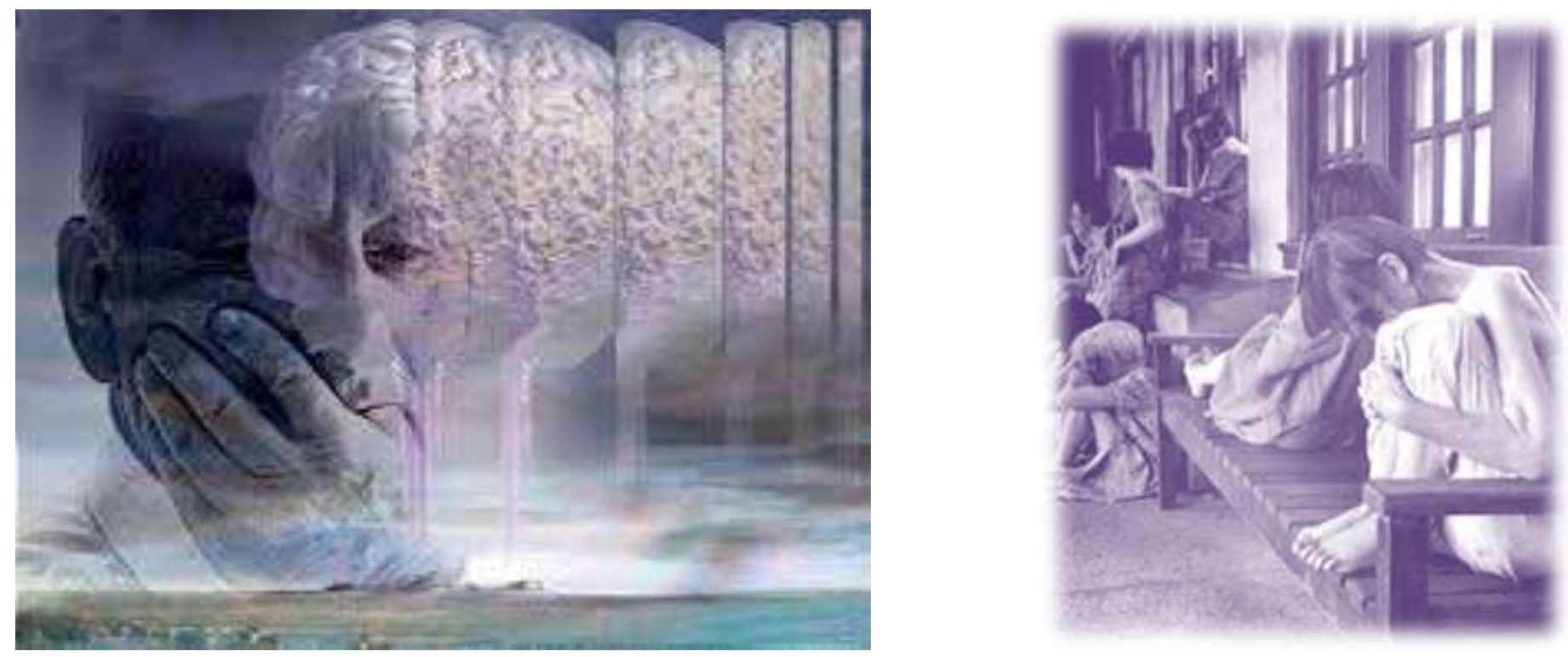

INNOVATIVE THINKING FOR THE REAL WORLD 

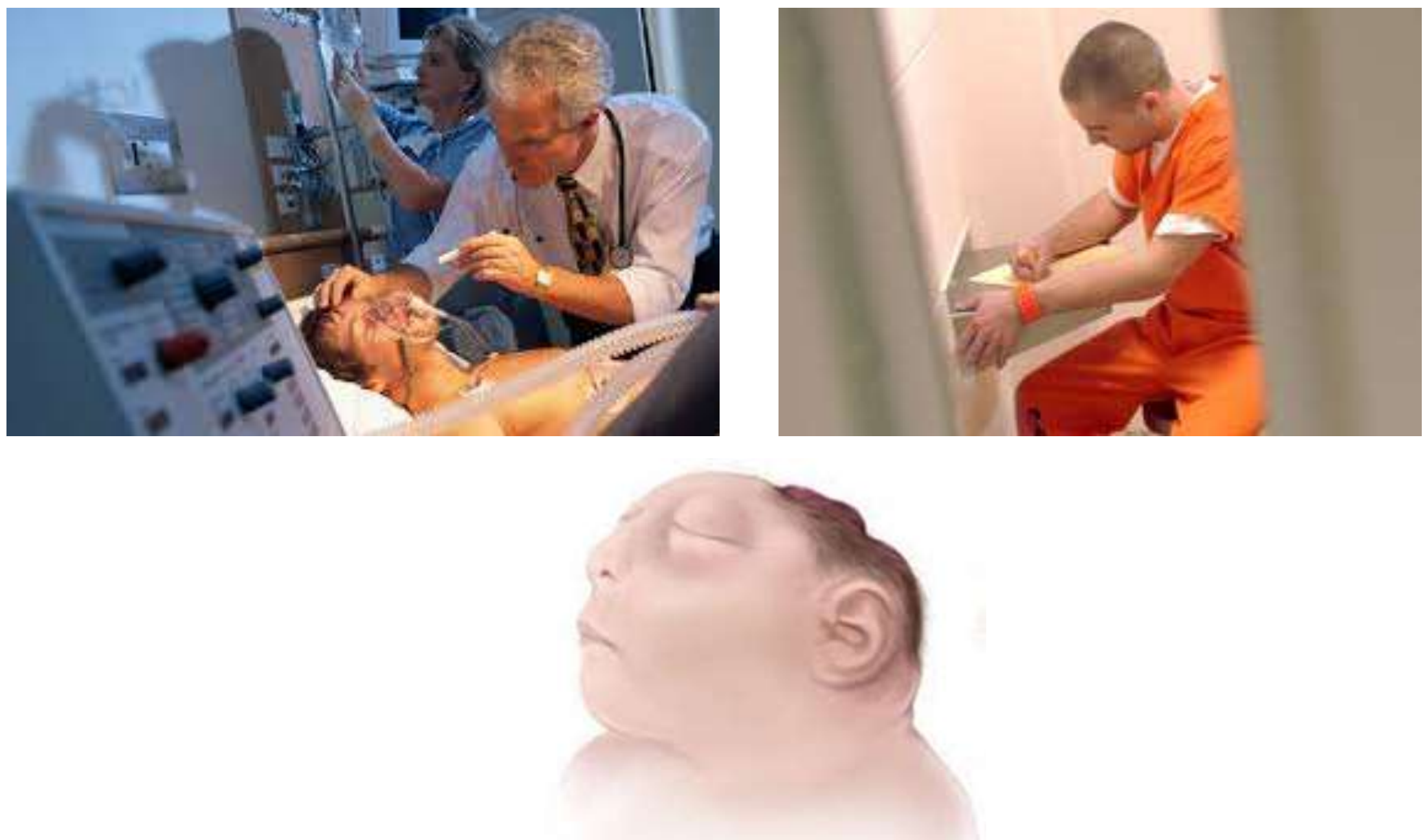

INNOVATIVE THINKING FOR THE REAL WORLD 


\section{2) To prevent premature declaration of death}

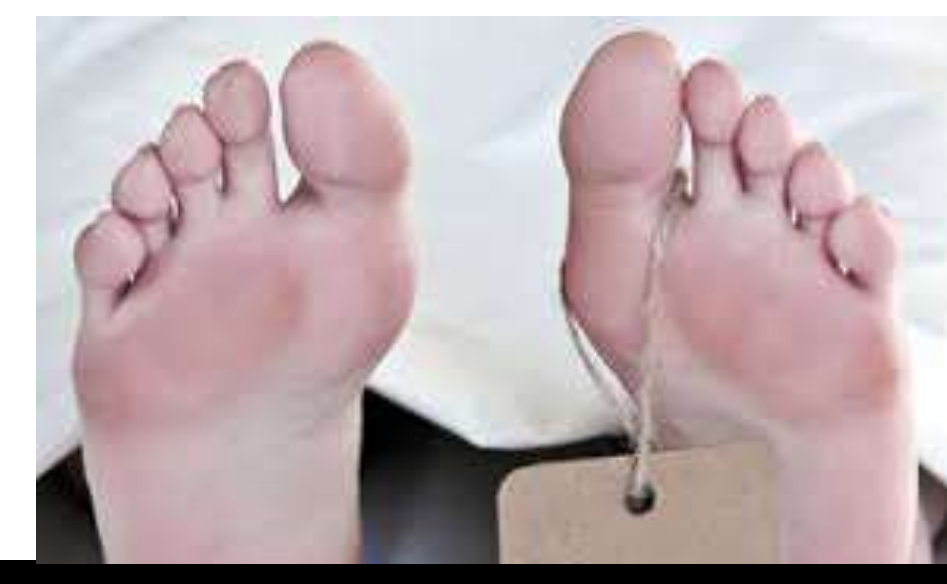

INNOVATIVE THINKING FOR THE REAL WORLD 


\section{3) Doctors are healers, not killers}
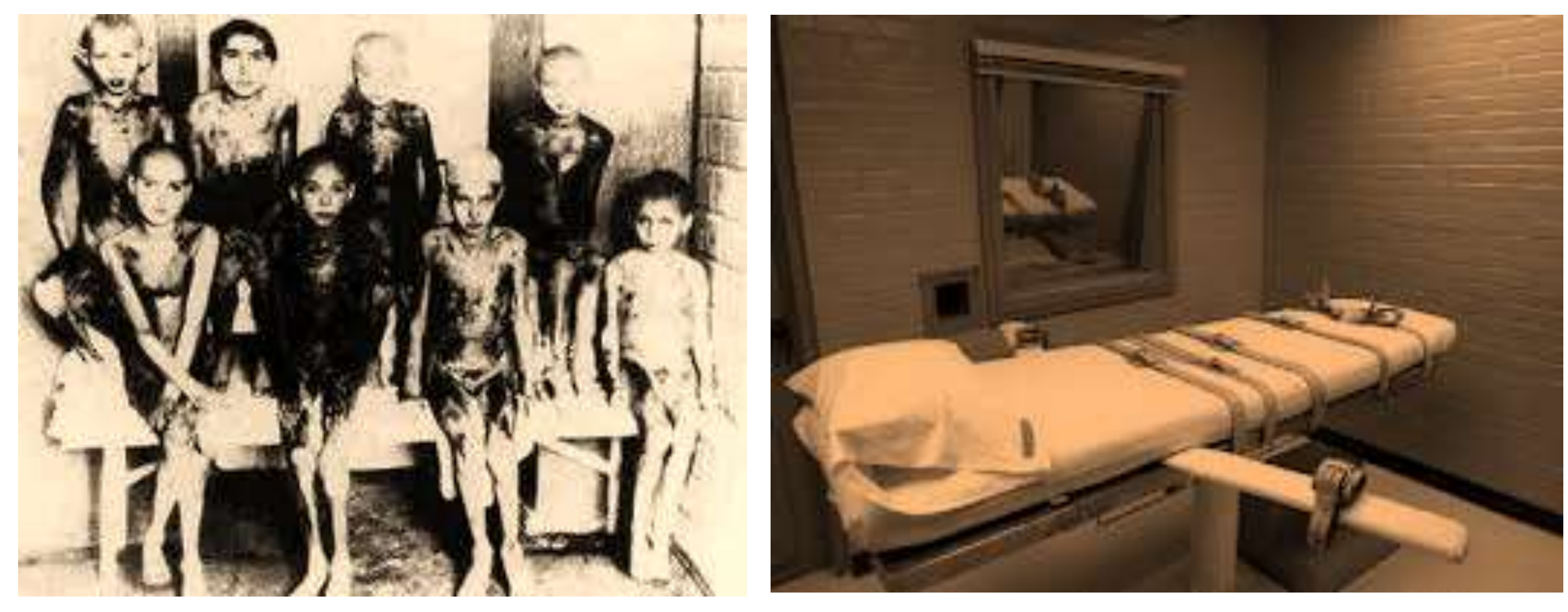

INNOVATIVE THINKING FOR THE REAL WORLD 


\section{4) To maintain public confidence}

"the ethical linchpin of a voluntary system of organ donation"

- John Robertson

INNOVATIVE THINKING FOR THE REAL WORLD 


\section{Dr Juro Wada (1922 - 2011)}
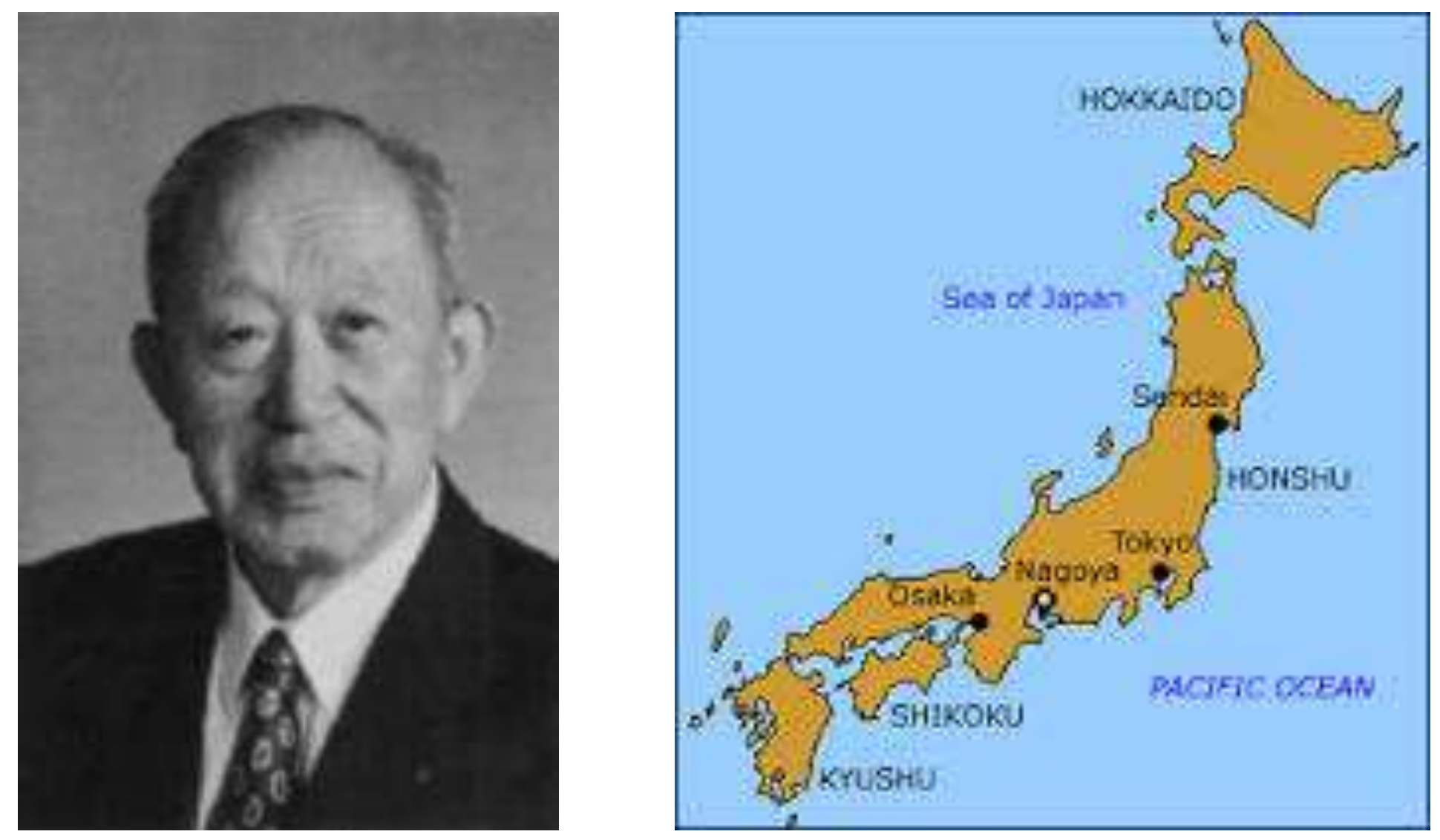

INNOVATIVE THINKING FOR THE REAL WORLD 


\section{Current Definition of Death}

\section{Brain stem death}

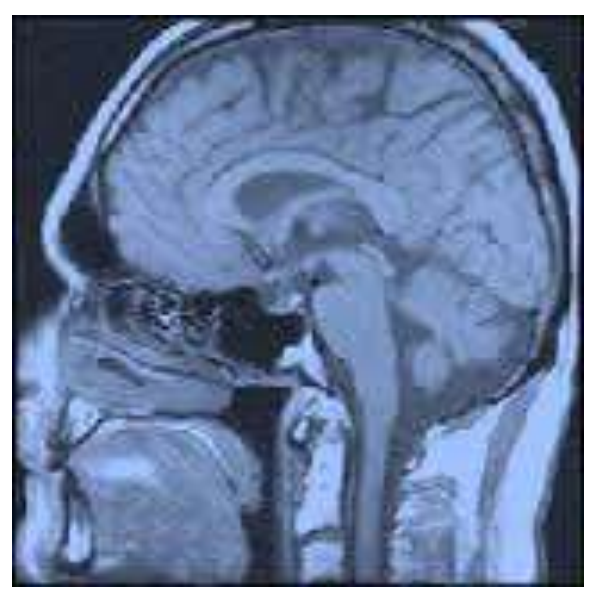

INNOVATIVE THINKING FOR THE REAL WORLD 


\section{Dead person, living body}

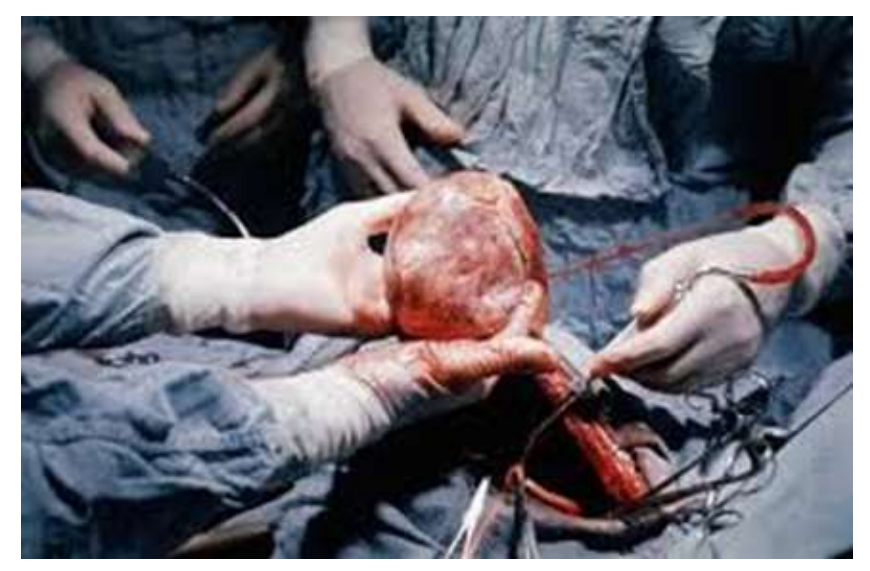

INNOVATIVE THINKING FOR THE REAL WORLD 


\section{Soulless death}

INNOVATIVE THINKING FOR THE REAL WORLD 


\section{Death in Abrahamic Faith Traditions}

- When the soul is separated from the body

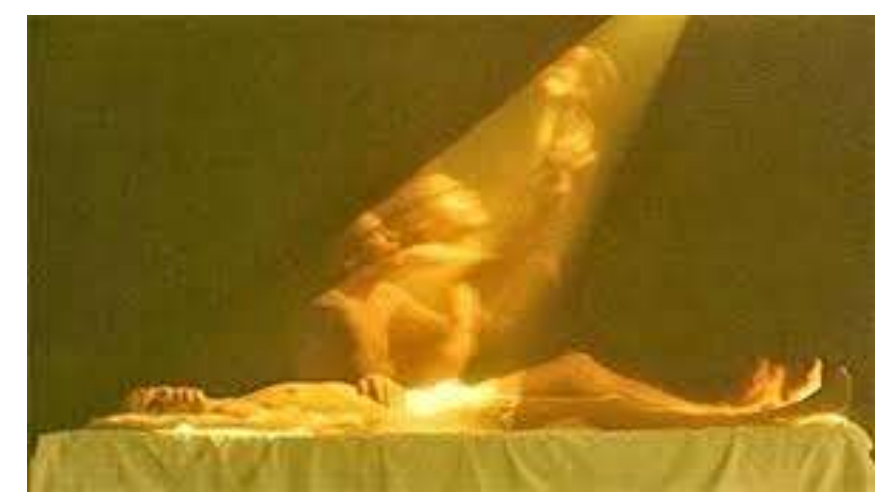

- When breathing and heartbeat have stopped

INNOVATIVE THINKING FOR THE REAL WORLD 


\section{Living person(!), living body}

INNOVATIVE THINKING FOR THE REAL WORLD 


\section{The DDR Revisited}

- But organ retrieval must not kill the donor

- Donor must be declared dead first

INNOVATIVE THINKING FOR THE REAL WORLD 


\section{"dead enough"}

Jay Baruch (2003)

\section{"being dead for the purposes of" John Tuohey (2009)}

INNOVATIVE THINKING FOR THE REAL WORLD 
"Heartbeat and blood pressure rise as the surgeon cuts into the supposedly dead organ donor, a similar reaction to a healthy person being attacked with a knife"

Dr David Wainwright Evans (Cardiologist, Queens College Cambridge)

"Postmortem examinations are carried out on dead bodies; organs are harvested from living ones. [The latter are] responsive to pain, requiring paralysing drugs, blood transfusion and anaesthetics for surgery"

Dr David J Hill (Consultant Anaesthetist, Huntingdon)

INNOVATIVE THINKING FOR THE REAL WORLD 
"No respectable, learned, and accepted Catholic moral theologian has said that the words of Jesus regarding the laying down of one's life for one's friend (John 15:13) is a command or even a license for suicidal consent for the benefit of another's continuation of earthly life."

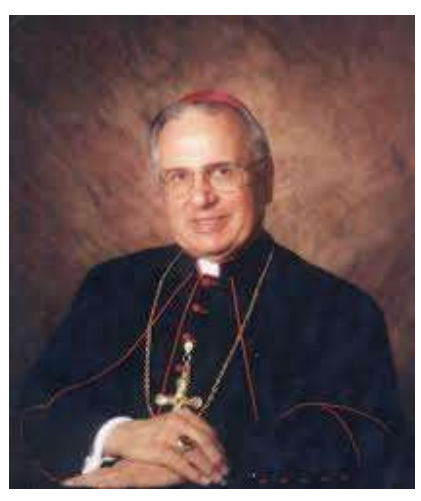

Bishop Fabian Bruskewitz

INNOVATIVE THINKING FOR THE REAL WORLD 


\section{RECOMMENDATIONS}

INNOVATIVE THINKING FOR THE REAL WORLD 


\section{1) Honesty \\ - in public campaigns; \& \\ - when obtaining consent}

INNOVATIVE THINKING FOR THE REAL WORLD 


\section{Current campaigns}

The Gift of

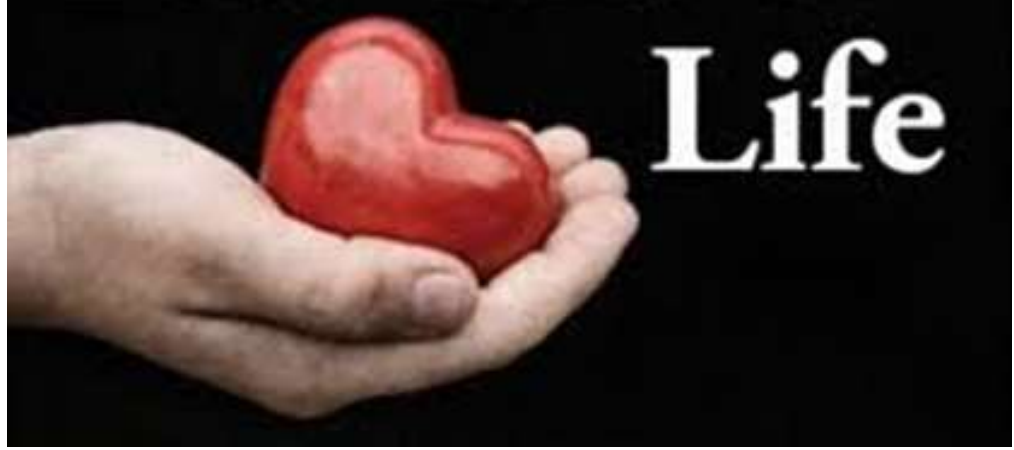

Donor Card

I would like to help someone to live after my death.

INNOVATIVE THINKING FOR THE REAL WORLD 

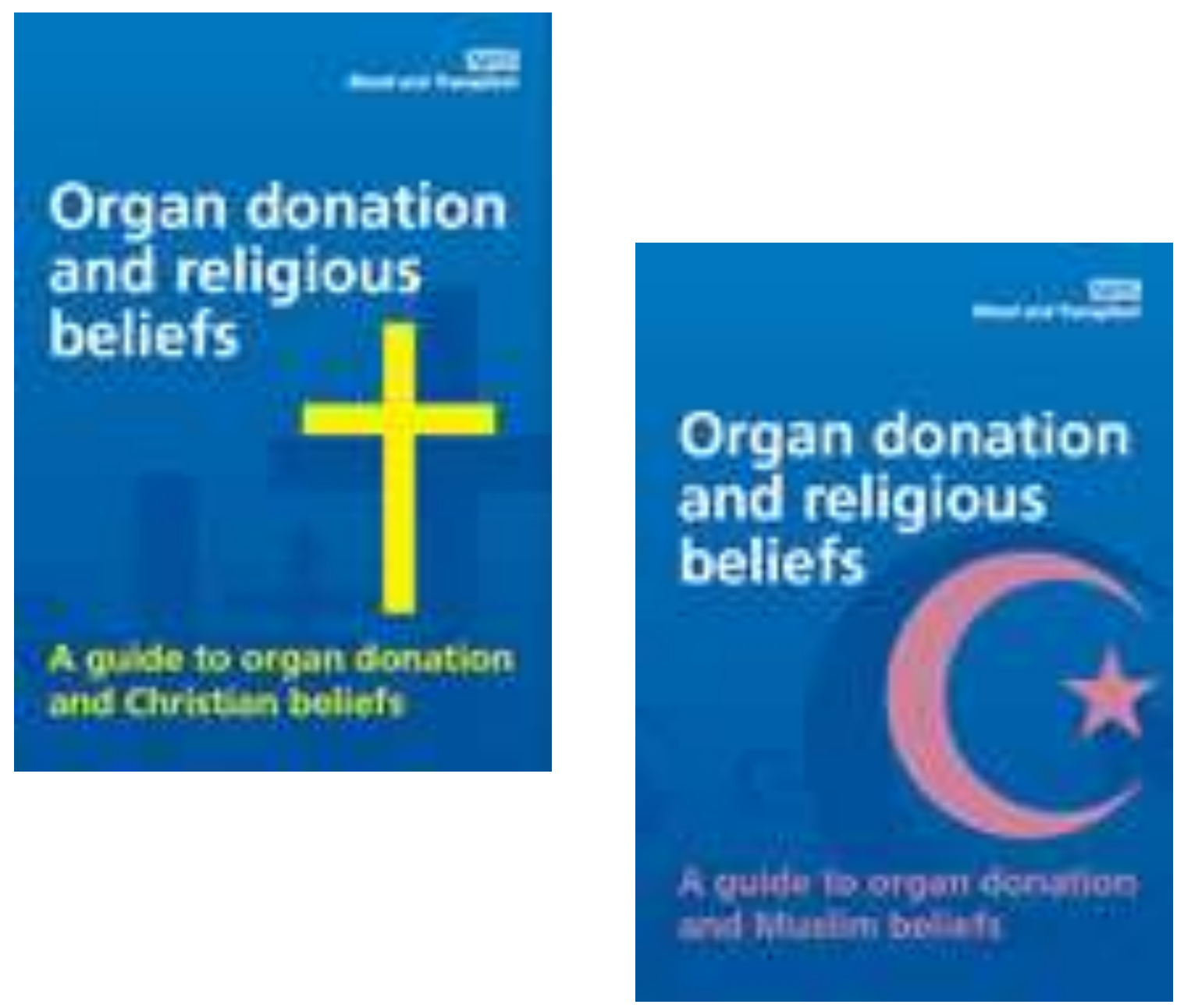

\section{Organ donation} and religious beliefs

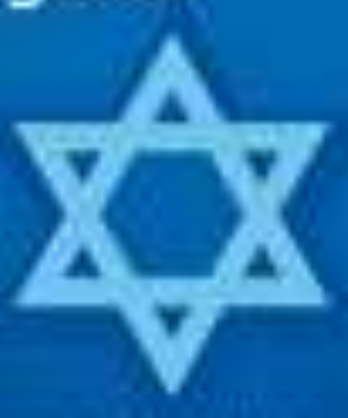

A guide vo organ docatiog and Inwish belints

INNOVATIVE THINKING FOR THE REAL WORLD 
"The current discourse between organ procurement organisations and the public is tainted with self-interest"

Frank Chaten (2013)

INNOVATIVE THINKING FOR THE REAL WORLD 

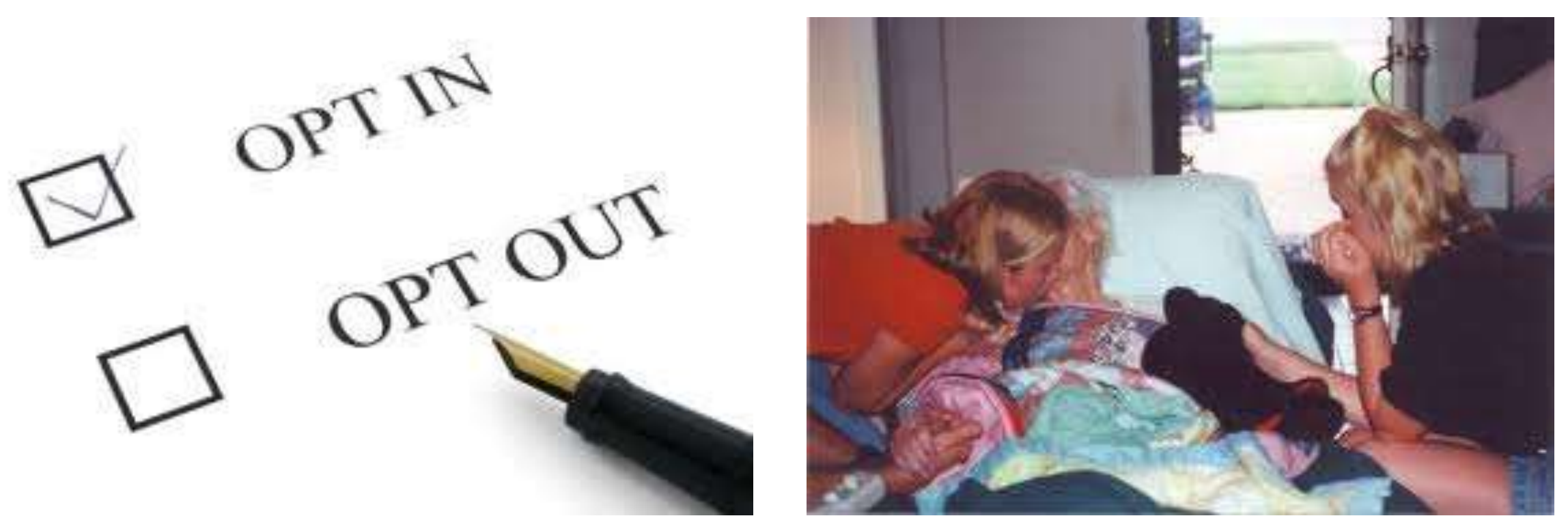

INNOVATIVE THINKING FOR THE REAL WORLD 


\section{2) Legal recognition for other definitions of death}

INNOVATIVE THINKING FOR THE REAL WORLD 


\section{The Gift "of Life"}

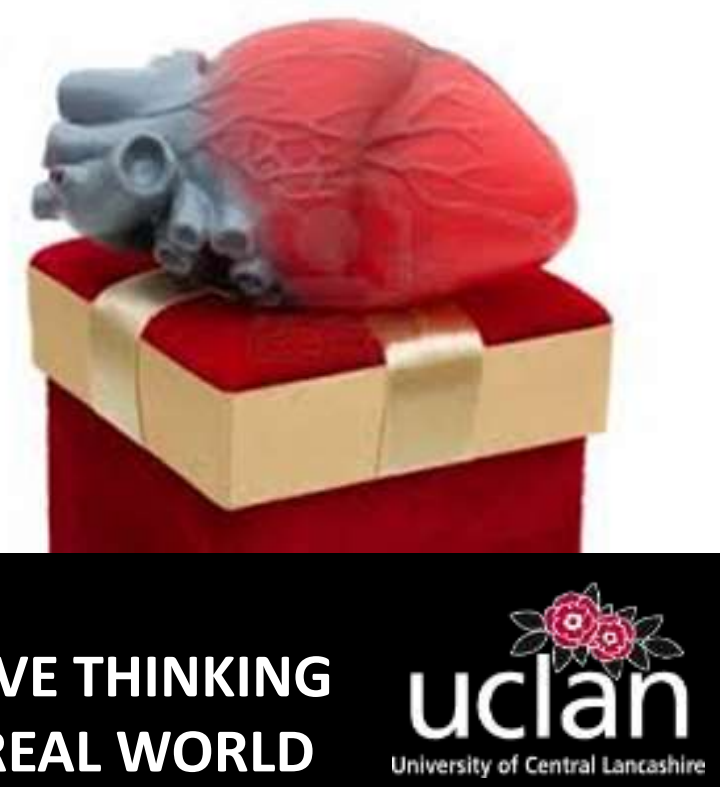




\title{
Thank you for your attention
}

\author{
kachoong@uclan.ac.uk
}

INNOVATIVE THINKING FOR THE REAL WORLD 